\title{
Work values of surviving and non-surviving managers during economic recession
}

\author{
Jan Selmer and Christian Waldstrøm \\ Department of Management, Aarhus School of Business, University of Aarhus, \\ Aarhus, Denmark
}

Work values

433

Received September 2006

Revised February 2007

Accepted February 2007

\begin{abstract}
Purpose - The purpose of this research is to compare work values of surviving and non-surviving managers during a period of general economic recession in Hong Kong associated with the Asian financial crisis.

Design/methodology/approach - Involving a natural field experiment, data on work values were collected from ethnic Chinese Hong Kong managers employed by local companies. The two sub-samples were established over the period of study, from 1995 to 1998, but all variables concerning these two groups were measured in 1995, well before the Asian financial crisis struck in 1997.

Findings - Results indicate that survivors attached more importance to independence in work and to have influence in the organisation than the non-survivors. On the other hand, non-surviving managers attached more importance to responsibility and to have an opportunity to meet people and interact with them than survivors.

Research limitations/implications - In future studies, the longitudinal investigation can be improved, non-Asian locations could be included, and more work values as well as other personal characteristics can be added.

Practical implications - The findings may have consequences for the strategic retention of managerial staff.

Originality/value - As opposed to the traditional perspective, that firms in dire straits may lose their best and brightest first, the findings suggest that in a general economic recession, it could be possible to retain managers capable to ride out the crisis.
\end{abstract}

Keywords Downsizing, Recession, Managers, Motivation (psychology), Hong Kong

Paper type Research paper

\section{Introduction}

Organisational downsizing and organisational decline has been frequent phenomena in recent decades due to fundamental and structural changes in the world economy. Whereas organisational downsizing is an intentional, proactive management strategy, organisational decline is an involuntary negative consequence of non-adjustment to adverse environmental circumstances. However, both phenomena may be associated with a reduction of the workforce over time, both by layoff of staff and attrition because employees leave for better job opportunities elsewhere (Freeman and Cameron, 1993). Traditionally, research has focused either on macro- or micro-oriented issues and few contributions have tried to integrate the two approaches (Bhattacharyya and Chatterjee, 2005; Feldman, 1995). Macro-oriented research has tried to identify environmental and organisational characteristics associated with organisational shrinkage and pressure to downsize (see Hambrick and D'Aveni, 1988;

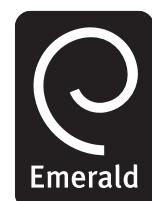

Career Development International Vol. 12 No. 5, 2007 pp. $433-445$ (C) Emerald Group Publishing Limited 1362-0436 
CDI

12,5

434

Kimberly and Miles, 1980) while their micro-oriented colleagues typically have studied the impact on organisational downsizing on individual employees (see Markham and McKee, 1991; Mone, 1994). However, a situation not often studied is when staff reductions occur as a response to organisational decline associated with a general economic downturn or recession of the national or regional economy. In such a situation, there could be a need to integrate the macro and micro perspective as the pressure to reduce staff may be more uniformly felt by organisations across industries. At the same time, the general economic downturn provides specific circumstances for employees with less alternative job opportunities. On the other hand, organisations need to preserve their core competencies and hence must retain key staff members for organisational survival and post-crisis redevelopment (see Allen et al., 2001; Lee, 2001; Nutt, 2004). Consequently, although staff reductions may be perceived as unavoidable, they may be undertaken in a differentiated manner with the outcome that the surviving managers may have other personal characteristics compared to their non-surviving colleagues.

The purpose of the current exploratory study is to examine this issue. During a period of general economic decline, surviving and non-surviving managers are compared in terms of their work values. These are relevant individual characteristics since it is difficult to disentangle values from motivation and behaviour. What one values, one is motivated to obtain or retain. Hence, work values may reflect some crucial personal traits of managers. So, a comparison of work values of surviving and non-surviving managers could be important to undertake for several reasons. Firstly, staff reductions associated with a general economic deterioration is not very often reported in the literature and the various consequences of such events needs to be better understood. Secondly, most studies deal with the effects of lay-offs on either the individual workers being laid off (e.g. Allen et al., 2001; Mishra and Spreitzer, 1998) or the survivors (e.g. Krackhardt and Porter, 1985) and not the antecedents of the layoffs. Finally, the results of this study are based on a rare but powerful natural field experiment (Green, 2004). The focus on both survivors and non-survivors - at a time before the crisis was evident - gives an unbiased perception of their differences in work values.

The location of the study was Hong Kong. The Asian financial crisis, initiated by the collapse of the Thai baht on July 2, 1997, threw Hong Kong into one of its worst general economic recessions in modern times with record high unemployment and a collapsing property market and stock market (Ingram, 1998; Leung and Hayashibara, 1998); Wolf, 1999). The investigation covers the period 1995 to 1998, reflecting the situation before and during the worsening part of the recession in Hong Kong.

\section{Literature review}

Two concepts are discussed as the main theoretical foundation for this study. First, the activities associated with a reduction of the workforce of a firm, organisational downsizing and decline, are dealt with. Second, there is a presentation of the specific set of values associated with the work context, work values.

\section{Organisational downsizing and decline}

Downsizing is a management strategy designed to improve organisational efficiency, productivity or competitiveness. It is an intentional organisational action 
differentiating it from the loss of market share, loss of revenues, or unwitting loss of employees that may occur during organisational decline. Downsizing also typically is associated with reductions in personnel, although other resources can also be cut. The focus of downsizing is to enhance the efficiency or effectiveness of the firm. It is either undertaken proactively or reactively to contain costs or to improve competitiveness. Hence, management may use downsizing as a defensive reaction to organisational decline or to enhance organisational performance. Either or, it is targeted at organisational improvement. Last, but not least, downsizing may impact work processes, intentionally or unintentionally. A reduced workforce means that fewer individuals are available to do the same amount of work. This may have an effect on what work gets done and in what way (Brockner et al., 1994; Freeman and Cameron, 1993; Tzafrir et al., 2006).

Organisational decline is distinctly different from downsizing. Decline is a negative consequence of maladaptation to a dysfunctional environmental condition. In other words, decline happens to an organisation and from a managerial perspective of the organisation, it is unintentional. Organisational decline must not necessarily involve a reduction in workforce but may do so to match losses in revenues or production. In such a case, downsizing is applied in response to organisational decline. As opposed to downsizing, organisational decline is not targeting improvement but is instead often associated with deteriorated efficiency leading to staff attrition. Consequently, a reduced workforce over time may have occurred due to unintentional attrition (organisational decline) or as a result of intentional reductions targeting organisational improvement (downsizing) (Freeman and Cameron, 1993).

\section{Work values}

Numerous studies have examined work values, rewards, and their relationships with other work-related organisational behaviours, such as work commitment and job satisfaction (Kalleberg, 1977; Kanchier and Wally, 1989; Loscocco, 1989; Mottaz, 1986, Loscocco, 1989; Pinfield, 1984; Walker et al., 1982; Wong and Chung, 2003; Wood et al., 2000), stress and performance (Siu, 2003), and organisational citizenship (Feather and Rauter, 2004; Ryan, 2002). Before proceeding to review the concept of work values, it is necessary to give some initial attention to the meaning of values.

One of the most prominent and influential writers on values and value systems is Rokeach (1973) who defines a value as a relatively stable construct, as "an enduring belief". Central to these definitions is the fact that values and value systems are thought of in relative terms; values in terms of preferences for behaviours or end-states relative to their converses and value systems in terms of the relative importance of any given value relative to others in the system. Work values have subtle but powerful influence on work life (Hofstede and Bond, 1984).

Since values are created in most types of the social interaction, the workplace is one of the major social environments in which values are created, shared and developed. Roe and Ester (1999) have provided an extensive review of the literature concerning values and work making a distinction between general values, or general life values, and values concerning specific life domains. While this distinction seems to be commonly agreed on, there is some debate over the relations between the two: While some argue that work values represent a subset of the general values, others argue that "taking a more holistic view integrating work and non-work values, may be more 
CDI

12,5

436 productive" (Elizur and Sagie, 1999) by stressing the structural similarity between work values and general values.

\section{Research question}

In a general economic downturn or recession, involving the national or regional economy, other job opportunities may not be numerous and few employees may want to leave their current employment voluntarily. Hence, organisational downsizing involving staff reductions may be the main strategy employed to try to arrest the organisational decline and achieve survival of the firm (Freeman and Cameron, 1993).

Downsizing should preferably be done very carefully as it is crucial not to lay off the wrong employee. In the short run, a company needs staff members with a capability of saving the company. To a certain extent, in a longer perspective, employees capable of re-developing the business further are also needed. Hence, both short-term survival and longer term re-development are contingent on that the company succeeds in retaining the right people and only dismisses employees that can be expected to contribute less to these two crucial tasks. Strategies for successful downsizing may have some common ingredients encompassing such a differentiated approach. Common components could include: Downsizing is undertaken based on recommendations from lower-level employees involving job and task analyses of how work is organised at the moment, use of both short-term (staff reduction) and long-term approaches (organisation redesign and change of the organisational culture), using internal means to identify areas of redundancy and inefficiency and targeting such areas for downsizing, and slowly moving towards less organised complexity while retaining essential core competencies and supporting functions (see Cameron et al., 1991; Cascio, 1993; Nutt, 2004).

In other words, if the ability to deal with the crucial task of the imminent survival of the firm, as well as longer term re-development, is reflected among the personal characteristics of the remaining managers, it is not unlikely that surviving managers have different work values than the non-survivors. This presumption leads to the following research question:

$R Q 1$. During periods of a general economic downturn of the regional economy, accompanied by downsizing of the work force of declining firms, do surviving and non-surviving managers have different work values?

\section{Method}

Place of investigation

Hong Kong covers an area of 1,075 square kilometres, about the size of New York City, and it is located south of the Chinese mainland. It was handed over to China in 1997 after 155 years of British colonial rule. Hong Kong is a modern, mostly urban metropolis that epitomizes a prosperous capitalist society with a similar per capita GDP as Britain. Currently it has a population of about 7 million, predominantly comprised of the Cantonese dialect group mainly originating from the adjacent province of Guangdong in mainland China (Cheung and Chow, 1999; Roberts, 1992).

Economic decline in the late 1990 s

With the collapse of the Thai baht on July 2, 1997, a chain reaction started Asia's economic turmoil to become known as the Asian financial crisis (Wolf, 1999). Hong 
Kong was less affected at first by this crisis, but less than a year after the handover to China, the economy had negative growth, unemployment had risen to a 15-year record of 4.5 per cent and property prices had collapsed an average of 40 per cent. Furthermore, the Hang Seng stock market index crashed from a high of more than 16,000 at its peak the previous year to below 7,000 (Ingram, 1998; Leung and Hayashibara, 1998). In 1998, Hong Kong experienced its first budget deficit which increased even further in 1999 (Economist, 2000). Tourism, one of the foundations of the Hong Kong economy, was hit. Being one of the few Asian economies not to devalue its currency, Hong Kong became one of the most expensive places in Asia (Economist, 1998). This along with the structural economic changes from a primarily industrial economy towards an economy based on the service sector (Siu, 2003), has undeniably brought some fundamental changes to people at all hierarchical levels.

\section{Data collection}

The data used in this study was extracted from a larger investigation involving a longitudinal three-panel, cross-cultural design. However, the current data set only contains ethnic Chinese Hong Kong managers employed by local companies. In the larger study, the work values of participants in this panel were measured in 1995 and 1998. Between those two measurements there was considerable panel attrition. Due to the adverse economic development in Hong Kong, many companies had a high staff turnover. A consistent reason for dropping out of the panel was that the managers had left their initial employment between the two measurements, voluntarily or involuntarily, and could not be traced. This created two sub-samples, those who stayed on and those who dropped out during the measurement period. The first group of managers will be labelled "survivors" $(n=73)$ and the second group 'non-survivors' $(n=41)$. In this study, all variables concerning these two groups were measured in 1995, well before the Asian financial crisis struck. Nevertheless, a longitudinal element remains in the data of this investigation since the separation of the survivor and the non-survivor group was established over the period of study from 1995 to 1998. The main characteristics of this investigation amounts to a rare, but powerful, natural field experiment (Green, 2004)

Surviving managers had a mean age of 34.92 years $(\mathrm{SD}=8.36)$ and an average tenure with their firms of 8.65 years $(\mathrm{SD}=9.62)$. The average age of the non-survivors was younger, 30.49 years $(\mathrm{SD}=6.34)$. They also had a shorter corporate tenure of 4.88 years $(\mathrm{SD}=6.66)$. As displayed by Table I, although the majority was male for both survivors and non-survivors, the overwhelming majority of the survivors were middle and top level managers while a clear majority of the non-survivors was first and middle level managers. Also, while the majority of the non-survivors were university graduates, most survivors had another educational qualification. As displayed by Table II, a MANOVA and ANOVA confirmed that there were significant differences in age, education, position, and tenure between surviving managers and non-survivors. These variables will be used as controls in the analysis.

\section{Instrument}

The questionnaire used the 24-item instrument on general work values developed by Elizur (1984), which has been thoroughly tested in various cultural contexts (Borg, 1986; Elizur et al., 1991) and is therefore appropriate for the this study. The scale was 


\section{CDI \\ 12,5}

438

\begin{tabular}{|c|c|c|c|c|}
\hline \multirow[b]{2}{*}{ Background variables } & \multicolumn{2}{|c|}{ Survivors $1995-1998^{a}$} & \multicolumn{2}{|c|}{ Non-survivors $1995-1998^{b}$} \\
\hline & Frequency & $\%$ & Frequency & $\%$ \\
\hline \multicolumn{5}{|l|}{ Gender } \\
\hline Male & 50 & 68.5 & 23 & 56.1 \\
\hline Female & 23 & 31.5 & 18 & 43.9 \\
\hline \multicolumn{5}{|l|}{ Position } \\
\hline First level management & 8 & 11.0 & 17 & 41.5 \\
\hline Middle level management & 47 & 64.4 & 23 & 56.1 \\
\hline Top level management & 18 & 24.7 & 1 & 2.4 \\
\hline \multicolumn{5}{|l|}{ Education } \\
\hline Other & 41 & 56.2 & 4 & 10.0 \\
\hline Professional qualification & 14 & 19.2 & 3 & 7.5 \\
\hline University degree & 18 & 24.7 & 33 & 82.5 \\
\hline
\end{tabular}

Table I.

Background of the sub-samples

Notes: ${ }^{\text {a }}$ Measured in $1995 ; 72 \geq n \geq 73$; ${ }^{\mathrm{b}}$ measured in $1995 ; 40 \geq n \geq 41$

Table II.

MANOVA and ANOVA for demographics by survivors/non-survivors $1995-1998(n=113)$

\begin{tabular}{lrrrrcc}
\hline & \multicolumn{2}{c}{ Survivors $^{\mathrm{b}}$} & & \multicolumn{2}{c}{$\begin{array}{c}\text { Non-survivors } \\
\text { Demographics }\end{array}$} \\
& Mean & SD & Mean & SD & Multi-variate effect & Uni-variate $F$-ratios \\
\hline Age & & & & & $2.70^{*}$ & \\
Education $^{\mathrm{d}}$ & 34.92 & 8.36 & 30.49 & 6.34 & & $8.66^{* *}$ \\
Gender $^{\mathrm{e}}$ & 1.69 & 0.85 & 1.32 & 0.69 & & $5.43^{*}$ \\
Position $^{\mathrm{f}}$ & 1.32 & 0.47 & 1.44 & 0.50 & & 5.04 \\
Tenure & 2.14 & 0.58 & 2.39 & 0.54 & & $4.84^{*}$ \\
& 8.65 & 9.62 & 4.88 & 6.24 & &
\end{tabular}

Notes: ${ }^{\mathrm{a}}$ Measured in $1995 ;{ }^{\mathrm{b}} n=72 ;{ }^{\mathrm{c}} n=41 ;{ }^{\mathrm{d}} 1=$ Other, $2=$ Professional qualification, $3=$ University degree; ${ }^{\mathrm{e}} 1$ = Male, $2=$ Female; ${ }^{\mathrm{f}} 1=$ First level management, $2=$ Middle level management, $3=$ Top level management; ${ }^{*} p<0.05 ; * *<<0.01$

administered to all respondents in its original English version. The questionnaire covers a wide variety of values categorized as cognitive (e.g. interest), affective (interpersonal relations) or instrumental (material outcomes). The same values also comprise a secondary classification, based on a distinction between rewards (pay, recognition, feedback, advancement and status) and resources (the remaining items).

The scale range is from 1 to 7 ( $1=$ very unimportant; $7=$ very important). The reliability score is alpha $=0.84$, which is acceptable (Nunnaly, 1978).

\section{Results}

Our research question was formally tested by means of MANCOVA and ANCOVA. As shown in Table III, the MANCOVA with age, education, position and tenure as covariates indicated an overall significant inter-group difference in work values between surviving managers and non-survivors $(F=4.01 ; p<0.01)$. ANCOVAs revealed four statistically significant differences among the mean importance of the work values between the two groups. Surviving managers had a higher mean score than non-survivors for independence in work $(F=64.27$; $p<0.001)$ and influence in the organisation $(F=3.98 ; p<0.05)$. On the other hand, non-survivors had a higher 


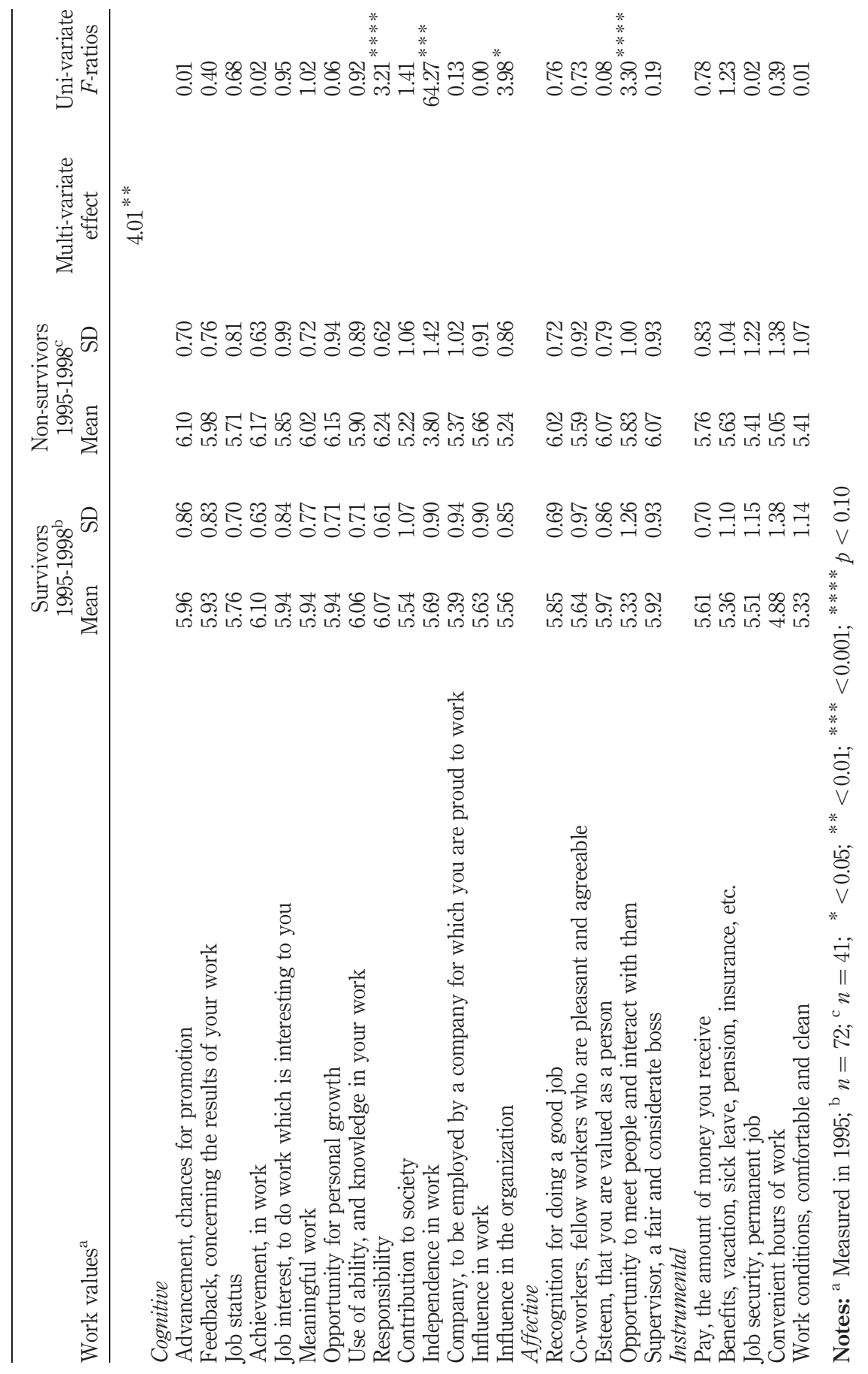

Work values

439

Table III. MANCOVA and ANCOVA for work values by survivors/non-survivors 1995-1998 $(n=113)$ 
CDI

12,5 mean score than surviving managers for opportunity to meet people and interact with them $(F=3.30 ; p<0.10)$ and responsibility $(F=3.21 ; p<0.10)$. These results provide an affirmative answer to our research question that during periods of a general economic downturn or recession of the national or regional economy accompanied by downsizing of the work force of declining firms, surviving and non-surviving managers may have different work values, at least in certain respects.

\section{Discussion}

Examining the background variables of the two groups of managers, as could have been expected, non-survivors were found to be younger, less well educated, and have shorter tenure than the survivors. The only surprise here was that non-surviving managers occupied higher positions than the survivors. One may speculate that younger managers with shorter tenure but with experience of higher managerial positions may have felt more mobile and also more attractive for the job market than older managers already since long established in a middle position in a company.

The main results are quite straightforward. Controlling for the inter-group discrepancies in background variables, we found that there was indeed a difference in work values between the surviving and non-surviving managers. The most distinct difference between these two groups of managers was in terms of the work value labelled independence in work. Survivors attached much more importance to this work value than non-survivors. This may reflect the change in working conditions brought about by the increasingly adverse economic conditions. The individual competency of surviving managers may be threatened as they have to assume the job tasks of their laid-off colleagues which may induce perceptions of job overload and lack of job clarity (Mishra and Spreitzer, 1998). In a context of rising uncertainty, when clear work directions may be scarce, managers that are able to perform independently may be more successful and better appreciated than others. Managers valuing independent work may also be more acutely needed to save the firm during the general economic downturn.

Other findings were not as significant but help to create a more nuanced picture. Not surprisingly, the surviving managers also thought it was more important to have influence in the organisation than the non-survivors. On the other hand, the group of non-surviving managers attached somewhat more importance to responsibility than survivors. The group of non-surviving managers also attached somewhat more importance to have an opportunity to meet people and interact with them than survivors, which may be explained by the fact that some of the non-surviving managers actively could have used their contacts to try to find another job.

\section{Limitations}

As always, the findings of this study may have some potential shortcomings affecting their interpretation and generality. First, the total sample of managers is not large, and the resulting number of managers in each group is small, especially the set of non-survivors. Although the MANOVA indeed indicated a significant inter-group difference, it is not unlikely that the indicated work value differences represent a conservative estimate of such differences between survivors and non-survivors. Similar to most statistical tests, the results of multivariate tests is contingent upon, among other things, the sample size. It has been claimed, that it could be quite 
problematic to identify effects, if they actually exist, in smaller sample sizes than 50 (Hair et al., 1995).

Second, while the managers that were no longer with their respective company in 1998 could have left their firms for a number of reasons, there was likely two main justifications. Either they left voluntarily by their own initiative or they were dismissed. It is not completely unlikely that dissatisfaction created by changing work conditions might have generated some employee turnover (Hom and Kinicki, 2001). However, given the severe economic recession in Hong Kong, at least at the end of the period of study, severely restricting the availability of alternative employment opportunities, it is more likely that a majority of the non-survivors were laid off.

Finally, the uniqueness of the location of the study may impose some limitations in the generality of our results. Although Hong Kong is a modern, mostly urban metropolis that epitomizes a prosperous capitalist society, as stated above, it is also part of a cultural context distant from those of many Western locations of a similar size and character. Acknowledging this, it may be reasonable to claim that the findings may have some relevance for locations with a similar cultural environment, as for example other places in Asia. However, it could be less appropriate to generalize these findings to other areas.

\section{Implications}

The findings suggest that it is not necessarily the least independent managers that remain in the organisation. That may have some consequences for the strategic retention of managerial staff. In times of general economic decline of the national or regional economy, companies may want to retain managers that can help them survive the period of hardship and they are helped in doing so by the lack of alternative employment. That may counteract the creation of a so called "cesspool syndrome" as proposed by Bedeian and Armenakis (1998). They argued that the most competent employees may quit voluntarily, leaving behind more inefficient and incompetent colleagues who will hasten the demise of the organisation. From that perspective, it is encouraging to find that managers who remained on their jobs especially valued independence in work. That type of work value could be useful in a crisis situation when individual initiatives of managers may become a valuable asset to any organisation. With reduced hierarchies and a decreased number of managers, downsized firms may rely more on trust and empowerment (see Mishra and Spreitzer, 1998; White and Mackenzie-Davey, 2003).

This finding may also relate to HR managers. While large-scale recessions and serious economic hardships might be far in-between, downsizing is likely to be part of the daily challenges faced by many companies in the globalized context, where outsourcing and organisational restructuring are common (Feldman, 1995). While there is still an ongoing debate about the seriousness of the "survivor syndrome", where it has been argued that the phenomenon can be avoided altogether with appropriate HRM practises (Baruch and Hind, 1999, 2000), the future of the company lies with the survivors. The findings of this study indicate that prior to the economic crisis, they may already be different than their colleagues - particularly in their preference for more independence. Therefore, HR managers may want to emphasize such personal work values as independence in work as special assets for organisational crisis management. 
CDI

12,5

442
Specifically, that may connect to the issue of career development in organizations. Although it has been claimed that a major and consistent shift away from the traditional career concept has taken place (see Arthur and Rousseau, 1996; Hall, 1996, 2002), this trend may be overemphasized and much has remained the same, not the least the role of the organization in shaping future careers (Baruch, 2006). HR managers may find that planning and managing the downsizing process is demanding (Marks and De Meuse, 2005), since they need to make sure that the right managers survive. In downsizing situations, succession planning may secure an organizations supply of future executives (Baruch, 2006). The results of this study may suggest to HR managers that it could be possible to retain suitable managers.

Future studies within this area may both try to improve on the limitations of this study and expand its scope. Although it is a difficult task, a more efficient handling of the longitudinal investigation would be beneficial. For obvious reasons, respondents may be reluctant to commit themselves to longitudinal studies. However, sufficient statistical power is necessary for more definite results of future studies. Although companies typically try to protect information regarding employer-employee relationships and details on the termination of such relations, more effort could profitably be spent by investigators of further studies to uncover reasons why employment relationships were terminated. To improve the external validity of future studies, other than Asian locations may be selected. An expansion of the scope of this type of studies could be undertaken by expanding the range of work values investigated. To enhance the possibility for organizations to benefit from this line of research in the future and to facilitate for HR managers and other executives to differentiate between the two groups of managers, future studies may want to include other measures and variables of personal characteristics of the employees relevant to the firm and its operations during general economic downturns.

\section{Conclusion}

The contribution of this highly exploratory study lies in the potentially reassuring message to business firms experiencing general economic downturns of the national or regional economy that surviving managers may have some key characteristics that could be necessary to ride out the crisis. This is different from the traditional perspective suggesting that companies in dire straits may lose their best and brightest first (see Bedeian and Armenakis, 1998).

\section{References}

Allen, T.D., Freeman, D.M., Russell, J.E.A., Reizenstein, R. and Rentz, J.O. (2001), "Survivor reactions to organizational downsizing: does time ease the pain?", Journal of Occupational \& Organizational Psychology, Vol. 74 No. 2, pp. 145-65.

Arthur, M.B. and Rousseau, D.M. (1996), "The boundaryless career as a new employment priciple”, in Arthur, M.B. and Rousseau, D.M. (Eds), The Boundaryless Career, Oxford University Press, New York, NY, pp. 3-20.

Baruch, Y. (2006), "Career development in organizations and beyond: balancing traditional and contemporary viewpoints", Human Resource Management Review, Vol. 16, pp. 125-38.

Baruch, Y. and Hind, P. (1999), "Perpetual motion in organizations: effective management and the impact of the new psychological contracts on 'survivor syndrome", European Journal of Work \& Organizational Psychology, Vol. 8 No. 2, pp. 295-307. 
Baruch, Y. and Hind, P. (2000), “'Survivor syndrome' - a management myth?”, Journal of Managerial Psychology, Vol. 15 Nos 1-2, pp. 29-46.

Bedeian, A.G. and Armenakis, A.A. (1998), "The cesspool syndrome: how dreck floats to the top of declining organizations", Academy of Management Executive, Vol. 12 No. 1, pp. 58-64.

Bhattacharyya, S. and Chatterjee, L. (2005), "Organizational downsizing: from concepts to practices”, Vikalpa: The Journal for Decision Makers, Vol. 30 No. 3, pp. 65-79.

Borg, I. (1986), “A cross culture replication on Elizur's facets of work values”, Multivariate Behavioral Research, Vol. 21, pp. 401-10.

Brockner, J., Konovsky, M., Cooper-Schneider, R., Folger, R., Martin, C. and Bies, R.J. (1994), "Interactive effects of procedural justice and outcome negativity on victims and survivors of job loss", Academy of Management Journal, Vol. 37 No. 2, pp. 397-410.

Cameron, K.S., Freeman, S.J. and Mishra, A.K. (1991), "Best practices in white-collar downsizing: managing contradictions", Academy of Management Executive, Vol. 5 No. 3, pp. 57-74.

Cascio, W.F. (1993), "Downsizing: what do we know? What have we learned?", Academy of Management Executive, Vol. 7 No. 1, pp. 95-105.

Cheung, G.W. and Chow, I.H. (1999), "Subcultures in greater china: a comparison of managerial values in the People's Republic of China, Hong Kong, and Taiwan", Asia Pacific Journal of Management, Vol. 16, pp. 369-87.

Economist (1998), "Business: the lunchbox tourists", Economist, pp. 67-8.

Economist (2000), "Economist Asia: atonement day", Economist, p. 50.

Elizur, D. (1984), "Facets of work values: a structural analysis of work outcomes", Journal of Applied Psychology, Vol. 69, pp. 379-89.

Elizur, D. and Sagie, A. (1999), "Facets of personal values: a structural analysis of life and work values", Applied Psychology: An International Review, Vol. 48 No. 1, pp. 73-87.

Elizur, D., Borg, I., Hunt, R. and Magyari-Beck, I. (1991), "The structure of work values: a cross-cultural comparison”, Journal of Organizational Behavior, Vol. 12, pp. 21-38.

Feather, N.T. and Rauter, K.A. (2004), "Organizational citizenship behaviours in relation to job status, job insecurity, organizational commitment and identification, job satisfaction and work values”, Journal of Occupational Psychology, Vol. 77, pp. 81-94.

Feldman, D.C. (1995), "The impact of downsizing on organizational career development activities and employee career development opportunities", Human Resource Management Review, Vol. 5 No. 3, pp. 189-222.

Freeman, S.J. and Cameron, K.S. (1993), “Organizational downsizing: a convergence and reorientation framework", Organization Science, Vol. 4 No. 1, pp. 10-30.

Green, D.P. (2004), "Field experimentation”, in Lewis-Beck, M.S., Bryman, A. and Liao, T.F. (Eds), The SAGE Encyclopedia of Social Science Research Methods,Vol. 1, Sage Publications, Thousand Oaks, CA, pp. 383-4.

Hair, J.F.J., Anderson, R.E., Tatham, R.L. and Black, W.C. (1995), Multivariate Data Analysis, Prentice-Hall Inc., Englewood Cliffs, NJ.

Hall, D.T. (1996), The Career is Dead - Long Live the Career, Jossey-Bass, San Francisco, CA.

Hall, D.T. (2002), Careers in and out of Organizations, Sage, Thousand Oaks, CA.

Hambrick, D.C. and D'Aveni, R.A. (1988), "Large corporate failures as downward spirals", Administrative Science Quarterly, Vol. 33 No. 1, pp. 1-23.

Hofstede, G.H. and Bond, M.H. (1984), "Hofstede's culture dimensions: an independent validation using Rokeach's value survey”, Journal of Cross-Cultural Psychology, Vol. 15, pp. 417-733. 
CDI

12,5

444
Hom, P.W. and Kinicki, A.J. (2001), "Toward a greater understanding of how dissatisfaction drives employee turnover", Academy of Management Journal, Vol. 44 No. 5, pp. 975-87.

Ingram, D. (1998), Hong Kong (Round Table), Vol. 346, April, pp. 124-5.

Kalleberg, A.L. (1977), "Work values and job rewards: a theory of job satisfaction”, American Sociological Review, Vol. 42 No. 1, pp. 124-43.

Kanchier, C. and Wally, R.U. (1989), "Factors influencing career change", International Journal for the Achievement of Counselling, Vol. 12 No. 4, pp. 309-21.

Kimberly, J. and Miles, R. (1980), The Organizational Life Cycle, Jossey-Bass Publishers, San Francisco, CA.

Krackhardt, D. and Porter, L.W. (1985), "When friends leave: a structural analysis of the relationship between turnover and stayers' attitudes”, Administrative Science Quarterly, Vol. 30 No. 2, pp. 242-61.

Lee, G. (2001), "Towards a contingent model of key staff retention: the new psychological contract reconsidered", South African Journal of Business Management, Vol. 32 No. 1, pp. 1-10.

Leung, J. and Hayashibara, M. (1998), "In the line of fire", Asian Business, Vol. 34 No. 9, pp. 22-9.

Loscocco, K.A. (1989), “The instrumentally oriented factory worker: myth or reality?”, Work and Occupations, Vol. 16 No. 1, pp. 3-25.

Markham, S.E. and McKee, G.H. (1991), "Declining organizational size and increasing unemployment rates: predicting employee absenteeism from within- and between-plant perspectives", Academy of Management Journal, Vol. 34 No. 4, pp. 952-66.

Marks, M.L. and De Meuse, K.P. (2005), "Resizing the organization: maximizing the gain while minimizing the pain of layoff, divestitures and closing", Organizational Dynamics, Vol. 34 No. 1, pp. 19-35.

Mishra, A.K. and Spreitzer, G.M. (1998), "Explaining how survivors respond to downsizing: the roles of trust, empowerment, and justice", Academy of Management Review, Vol. 23 No. 3, pp. 567-89.

Mone, M.A. (1994), "Relationships between self-concepts, aspirations, emotional responses and intent to leave downsizing organizations", Human Resource Management, Vol. 33, pp. 281-98.

Mottaz, C.J. (1986), "Gender differences in work satisfaction, work-related rewards and values, and the determinants of work satisfaction", Human Relations, Vol. 39 No. 4, pp. 359-77.

Nunnaly, J. (1978), Psychometric Theory, McGraw-Hill, New York, NY.

Nutt, P.C. (2004), “Organizational de-development”, Journal of Management Studies, Vol. 41 No. 7 , pp. 1083-103.

Pinfield, L.T. (1984), “A comparison of pre- and post-employment work values", Journal of Management Studies, Vol. 10 No. 3, pp. 363-70.

Roberts, D. (Ed.) (1992), Hong Kong 1992: A Review of 1991, Government Information Services: Hong Kong, Hong Kong.

Roe, R.A. and Ester, P. (1999), "Values and work: empirical findings and theoretical perspective", Applied Psychology: An International Review, Vol. 48 No. 1, pp. 1-21.

Rokeach, M. (1973), The Nature of Human Values, Free Press, New York, NY.

Ryan, J.J. (2002), "Work values and organizational citizenship behaviors: values that work for employees and organizations", Journal of Business and Psychology, Vol. 17 No. 1, pp. 123-32. 
Siu, O.-1. (2003), "Job stress and job performance among employees in Hong Kong: the role of Chinese work values and organizational commitment", International Journal of Psychology, Vol. 38 No. 6, pp. 337-47.

Tzafrir, S.S., Mano-Negrin, R., Harel, G.H. and Rom-Nagy, D. (2006), "Downsizing and the impact of job counselling and retraining on effective employee responses", Career Development International, Vol. 11 No. 2, pp. 125-44.

Walker, J.E., Tausky, C. and Oliver, D. (1982), "Men and women at work: similarities and differences in work values within occupational grouping", Journal of Vocational Behavior, Vol. 20, pp. 7-36.

White, M. and Mackenzie-Davey, K. (2003), "Feeling valued at work? A qualitative study of corporate training consultants", Career Development International, Vol. 8 No. 5, pp. 228-34.

Wolf, C. Jr (1999), "Asia gets back on its feet”, Hoover Digest, No. 4.

Wong, C.S. and Chung, K.M. (2003), "Work values of chinese food service managers", International Journal of Contemporary Hospitality Management, Vol. 15 No. 2, pp. 66-75.

Wood, J., Wallace, J. and Zeffanc, R.M. (2000), Organizational Behavior: A Global Perspective, 2nd ed., John Wiley \& Sons, Singapore.

\section{Further reading}

Guest, D.E. (2004), "The psychology of the employment relationship: an analysis based on the psychological contract”, Applied Psychology: An International Review, Vol. 53 No. 4, pp. 541-56.

Mottaz, C.J. (1988), "Determinants of organizational commitment", Human Relations, Vol. 41 No. 6, pp. 467-82.

\section{Corresponding author}

Christian Waldstrøm can be contacted at: cwa@asb.dk

To purchase reprints of this article please e-mail: reprints@emeraldinsight.com Or visit our web site for further details: www.emeraldinsight.com/reprints 